\title{
Effect of Social Jetlag on Sleep and Respiratory Disturbance in Young Patients with Obstructive Sleep Apnea Syndrome
}

\author{
Hyunjin Jo ${ }^{1}$, Eunhee $\mathrm{Jang}^{2}$, Su Jung Choi ${ }^{1,3}$, Sooyeon $\mathrm{Suh}^{2}$, Eun Yeon Joo ${ }^{1}$ \\ ${ }^{1}$ Department of Neurology, Neuroscience Center, Samsung Medical Center, Sungkyunkwan University School of Medicine, Seoul, \\ ${ }^{2}$ Department of Psychology, Sungshin Women's University, Seoul, \\ ${ }^{3}$ Department of Nursing, Department of Clinical Nursing Science, Samsung Medical Center, Sungkyunkwan University School of Medicine, \\ Seoul, Korea
}

\author{
사회적 시차가 젊은 폐쇄성 수면무호흡증 환자의 수면과 호흡 장애에 미치는 영향 \\ 조현진 ${ }^{1}$, 장은희 ${ }^{2}$, 최수정 ${ }^{1,3}$, 서수연 $^{2}$, 주은연 ${ }^{1}$ \\ 성균관대학교 의과대학 삼성서울병원 신경과, 뇌신경센터, ${ }^{1}$ 성신여자대학교 심리학과, ${ }^{2}$ 삼성서울병원 간호부, 성균관대학교 임상간호대학원 ${ }^{3}$
}

Received November 13, 2020 Revised December 10, 2020 Accepted December 15, 2020

Address for correspondence

Eun Yeon Joo, MD, PhD

Department of Neurology,

Neuroscience Center,

Samsung Medical Center,

Sungkyunkwan University

School of Medicine, 81 Irwon-ro,

Gangnam-gu, Seoul 06351, Korea

Tel: +82-2-3410-3597

Fax: $+82-2-3410-0052$

E-mail: eunyeon.joo@gmail.com

Objectives: Circadian misalignment may increase the risk of obesity and related obstructive sleep apnea (OSA). Considerable young adults have social jetlag (SJL), which is defined as the time discrepancy between workdays and free days. We aim to evaluate the relationship between SJL and sleep and respiratory disturbance in patients with untreated OSA patients. Methods: A total of 180 OSA patients under the age of 50 [mean $38.3 \pm 8.0 \mathrm{y}, 93.3 \%$ male, mean apnea-hypopnea index (AHI) 38.2 $\pm 27.4 / \mathrm{h}$ ] were recruited from the university affiliated sleep clinic and fulfilled sleep-related questionnaires including Munich Chronotype Questionnaire (MCTQ). SJL was defined as the difference in sleep midpoints between work and free days. Patients were divided into three groups with SJL less than 1 hour, 1-2 hours, and 2 hours or more and the clinical and sleep data of each group were compared. Results: $51.6 \%(n=93)$ suffered from significant SJL ( $\geq 1$ h). Patients with $\geq 2$ h of SJL ( $16.6 \%, n=30$ ) had the largest neck circumference (NC). AHI and sleep parameters were not significantly different among groups except lowest oxygen saturation (LoS) was the lowest in the group of $\geq 2 \mathrm{~h}$. SJL was positively correlated with body mass index and NC and negatively correlated with LoS after adjusting for age and sex. Conclusions: About a half of young adults with OSA have significant SJL more than $1 \mathrm{~h}$. This study suggests that SJL is associated with being overweight, while it seems not increase the severity of OSA nor deteriorate sleep quality in young adults.

J Sleep Med 2020;17(2):181-187

Key Words: Obstructive sleep apnea, Circadian rhythm, Chronotype, Sleep, Obesity.

서 론

폐쇄성 수면무호흡증(obstructive sleep apnea, OSA)은 수 면 중 반복적으로 전체 또는 부분 기도 폐쇄로 인해 저산소 증, 빈번한 각성 등이 유발되는 수면질환으로, 국내 남성에 서 $27.1 \%$, 여성에서 $16.8 \%$ 정도로 흔한 질환이다. ${ }^{1,2} \mathrm{OSA}$ 환 자에서의 수면 중 호흡 장애는 야간 수면의 질 저하, 과도한

This is an Open Access article distributed under the terms of the Creative Commons Attribution Non-Commercial License (https://creativecommons.org/licenses/by-nc/4.0) which permits unrestricted non-commercial use, distribution, and reproduction in any medium, provided the original work is properly cited.
주간 졸림 등을 유발하며, 우울증을 비롯한 기분장애 및 전 신성 고혈압, 당뇨, 관상동맥 질환, 뇌졸중의 발생과 이로 인 한 사망률 증가에도 영향을 끼치는 것으로 보고되고 있다. ${ }^{3-8}$ 비만, 두꺼운 목 둘레(neck circumference, NC), 노화, 남성, 두개안면기형, 내분비 질환, 음주와 안정제 등이 잘 알려져 있는 OSA의 위험 인자이고, ${ }^{9}$ 최근에는 일주기 리듬(endogenous circadian rhythm)이 무호흡의 발생 및 지속 시간과 연관 있음이 보고된 바 있다. ${ }^{10,11}$ 일주기 리듬의 장애(circadian disruption)가 OSA를 악화시키는지에 대한 연구는 아 직 부족하지만, 교대 근무자에서 OSA가 악화된다는 것은 
이미 잘 알려져 있다. ${ }^{12}$ 아직 그 중요성이 덜 알려져 있기는 하지만 현대인들이 직면하고 있는 만성적인 일주기 장애가 사회적 시차(social jetlag, SJL)이다. ${ }^{13}$

현대 사회에서 대다수는 아침 일찍 일을 시작하는 직장 생 활을 하고 있는데, 저녁 시간에는 업무나 개인적인 일로 늦 게 자는 경우가 많기 때문에 늘 수면부족에 시달리고, 이에 대한 보상 심리로 주말에 몰아서 자는 경우가 많다. 이렇게 사회적으로 요구되는 일정(예: 이른 등교시간, 출근시간)으 로 인해 개인 고유의 생체 시계(biological clock)와 불일치를 보이는 것을 장거리 항공여행에 빗대어 사회적 시차 $(\mathrm{SJL})$ 라 고 한다. ${ }^{14}$ 유럽의 working population을 대상으로 일주기 유 형 선호도 질문지(Munich Chronotype Questionnaire, $\mathrm{MCTQ}$ )를 이용하여 사회적 시차를 조사한 연구에서 대상자 의 약 $2 / 3$ 가 1 시간 이상의 사회적 시차를 보이고, $1 / 3$ 이 2 시 간 이상의 사회적 시차를 보였다. ${ }^{13}$ 이러한 사회적 시차는 나 이가 들수록 감소를 보이는데, ${ }^{13}$ Parsons 등과 Wong 등의 연 구에서는 50 세 미만에서 1 시간 이상의 사회적 시차를 보인 사람이 $59.1 \%$ 인데 반해, 50 세 이상에서는 1 시간 이상의 사회 적 시차를 보이는 사람이 $25.4 \%$ 였고, Koopman 등의 보고 에 의하면 61세 이상에서 사회적 시차가 1 2시간인 사람이 $24 \%, 2$ 시간 이상의 사회적 시차를 보이는 사람이 $19 \%$ 로 감 소한다..$^{15-17}$ 이는 고령에서 퇴직으로 인한 사회적 시계의 부 재가 사회적 시차를 감소시킨 것으로 설명할 수 있다. 선행 연구에서는 사회적 시차가 발생할 경우 만성적인 수면박탈, 건강을 저해하는 행동(예: 흡연, 음주, 카페인 섭취 등), 높은 체질량지수(body mass index, BMI), 만성질환에 대한 위험 성과 관련이 있는 것으로 보고되었다. ${ }^{13,18}$

사회적 시차는 만성적인 일주기 장애 그 차체로 수면무호 흡증에 영향을 줄 수 있고, 뿐만 아니라 사회적 시차로 인해 유발된 건강을 저해하는 행동 습관 및 높은 $\mathrm{BMI}$, 만성질환 등에 의해 수면 무호흡에 영향을 줄 수 있다. 하지만 아직까 지 OSA에서 사회적 시차의 영향에 대해 연구된 바는 없다.

본 연구의 가설은 사회적 시차가 발생 가능한 젊은 OSA 환자에서, 사회적 시차가 수면호흡장애와 동반된 수면의 질 과 연관성이 있을 것으로 설정했다. 이에 50세 미만의 OSA 환자에서의 사회적 시차의 분포를 확인하고, 사회적 시차에 따른 수면다원검사 결과를 분석하여 관련성 있는 수면지표 를 찾고자 하였다.

\section{방 법}

\section{연구 참여자}

본 연구는 의무기록을 이용한 후향적 조사로, 2018년 10월
부터 2019년 7월까지 삼성서울병원 수면검사실에 수면다원 검사를 받기 위해 내원한 환자들을 대상으로 하였고, 수면다 원검사로 확인된 수면 무호흡-저호흡지수(apnea-hypopnea index, AHI)가 시간당 5회 이상인 50세 미만의 환자를 선별하였다. 50세 이상의 환자는 사회적 시차가 작고, 반면 수면 무호흡은 악화되기 때문에 본 연구에서는 50세 미만으 로 한정하여 분석하였다. 조사 기간 내 총 869명의 환자가 수 면다원검사를 시행하였고, 이 중 OSA로 진단된 50세 미만 환 자는 249 명이었다. 이 중 교대근무자 17 명과 설문지 작성이 미비한 52명을 제외한 180 명을 최종 대상자로 선정했다 (Fig. 1). 본 연구에 사용된 연구 기준, 방법 및 평가는 삼성 서울병원 기관윤리심의위원회의 심의에서 승인 받았고(승 인번호 2020-03-194), 기관윤리심의위원회의 관리감독하에 시행되었다.

\section{연구 도구}

\section{수면다원검사}

Embla N7000(Medcare Flaga, Reykjavik, Iceland) 장비 로 수면검사를 시행했다. 기본 검사 항목으로 6채널의 뇌파 (C3-A2, C4-A1, F3-A2, F4-A1, O1-A2, O2-A1)와 4채널 의 안전위도(electro-oculogram), 1 채널의 턱근전도(chin electromyography)를 기록하여 수면의 단계와 각성 빈도를 측정하였다. 호흡 관련 측정을 위해서 압력 센서를 이용하여 비강 공기압을 측정하였다. 호흡 노력을 보기 위해 흥곽과 복부 벨트를 이용하여 호흡 움직임을 측정하였다. Oximetry 를 이용하여 검지손가락에서 산소포화도를 측정하였고, 소 리 센서로 코골이 강도를 측정하였다. 다리 움직임을 보기 위해 2 채널의 양측 전경골근(anterior tibialis)의 근전도를 측

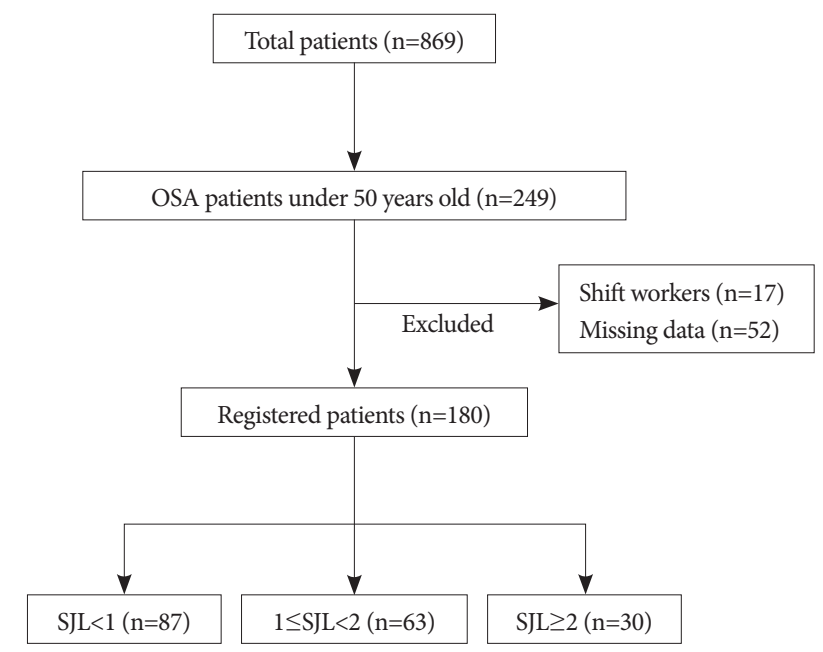

Figure 1. Flow chart of the study population. 
정하였다. 수면 자세를 확인하는 체위 센서와 심전도를 함께 측정하며 동시에 비디오를 기록하여 수면 중 행동장애나 자 세를 기록하였다.

수면단계와 호흡지수 등 수면다원검사 평가는 American Academy of Sleep Medicine Manual에 따라 판독했다. ${ }^{19}$ 수 면구조는 뇌파, 근전도, 안구 움직임 등을 통해 수면 단계를 분석한 것으로, sleep stage 1(N1), sleep stage 2(N2), sleep stage 3(N3), rapid eye movement(REM) 수면의 비율로 조 사하였다. 수면 양상은 수면 잠복기(sleep latency), 입면 후 각성시간(wakefulness after sleep onset), 총 수면시간(total sleep time), 수면 효율(sleep efficiency)로 측정하였고, 각성 지수(arousal index) 등을 평가하였다. 무호흡(apnea)은 10초 이상 호흡이 멈추는 것으로 비강의 온도와 압력 센서를 통해 공기 흐름이 $90 \%$ 이상 감소하는 상태를 말하며, 호흡저하 (hypopnea)는 공기 흐름이 10초 이상 $30 \%$ 이상 감소를 보이 면서 산소포화도가 $4 \%$ 이상 떨어지는 경우, 또는 뇌파상 각 성이 관찰되는 경우로 정의하였다. AHI가 시간당 5 회 이상 이면서 주간졸림, 피로 등 주간 증상 또는 수면무호흡, 코골 이가 있는 경우에 OSA로 진단하였다. 산소불포화지수(oxygen desaturation index, ODI)는 기저상태(baseline)와 비교 하여 시간당 혈중 산소포화도가 $3 \%$ 이상 감소하는 횟수로 정의하였다.

\section{$\mathrm{MCTQ}$ 설문지}

본 연구는 Roenneberg 등이 개발하고, Suh 등이 타당화 한 한국어판 일주기 유형 선호도 질문지 $(\mathrm{K}-\mathrm{MCTQ})$ 를 사용 하였다. ${ }^{20,21}$ 해당 질문지는 실제 수면 시간과 활동 시간을 측 정하여 개인의 일주기 선호 유형(chronotype)을 파악하는데 사용되는데, 본 연구에서는 해당 질문지의 응답을 통해 참여 자들의 평일과 휴일의 수면 시간을 측정하였다.

\section{$\mathrm{MCTQ}$ 지표 분석}

$\mathrm{MCTQ}$ 의 응답을 통해 수면 시작 시각(sleep onset, $\mathrm{SO}$ )과 수면이 끝나는 시각(sleep end, SE)을 파악하여, 이를 통해 수면 기간[sleep duration(SD)=SE-SO]과 중간수면[mid sleep $(\mathrm{MS})=\mathrm{SO}+\mathrm{SD} / 2$ ]을 계산하였다. 사람들은 중간수면 시점에 서 가장 깊은 잠에 들며, 중간수면을 바탕으로 시간 기반 일 주기 유형인 교정된 휴일 중간수면(mid-sleep time on free days corrected for sleep debt accumulated over the work week, MSFsc)을 측정할 수 있다.22 생물학적 시계와 사회적 시계 사이의 불일치인 사회적 시차는 자유일 수면 중간 점 (mid-sleep time on free days, MSF)에서 근무일 수면 중간 점(mid-sleep time on work days, MSW)의 차이로 계산하 였다(social jetlag=|MSF-MSW|). ${ }^{14}$ 본 연구 집단에서 사회 적 시차는 0 4.37시간 범위를 보였고, 선행 연구에 따라 사 회적 시차가 1 시간 미만인 그룹, 1 시간 이상 2 시간 미만인 그룹, 2 시간 이상인 그룹으로 분류하였다. ${ }^{17}$

\section{기타 설문지}

대상자는 추가적으로 엡워스 주간졸림증 척도(Epworth Sleepiness Scale, ESS), 한국어판 벡 우울척도 II(Korean version of Beck Depression Inventory II, K-BDI-II)를 작성하 였다. 23,24

현재의 흡연 여부(예/아니오), 음주 여부(예/아니오), 고혈 압 및 당뇨병의 동반 여부(예/아니오)에 대해서도 설문지를 통해 조사하였다.

\section{자료 분석}

수집된 자료는 유의수준 0.05 로 하여 윈도우용 SPSS 20.0 (IBM Corp., Armonk, NY, USA)을 이용하여 다음과 같이 분석하였다. 대상자의 일반적 특성은 빈도와 백분율, 평균과 표준편차를 이용하였다. 세 군간 차이는 일원배치분산분석 (one-way analysis of variance analysis)과 사후검정(Scheffe test)으로 검증하였다. 사회적 시차는 나이 및 성별에 따라 달라지기 때문에, 사회적 시차와 변수들 간의 상관관계는 나 이와 성별을 보정한 편상관분석(partial spearman correlation)을 이용하여 하였다.

\section{결 과}

\section{사회적 시차에 따른 대상자 전체의 일반적 특성 및 설문 비교}

본 연구 대상자의 평균 연령은 38.3세( $\pm 8.0,15.0$ 49.0세) 였으며, 남성 93.3\%(n=168)를 포함하였으며, 사회적 시차 평 균 값은 1.18 ( $\pm 0.85,0.0 \sim 4.37$ 시간)시간이었다. 사회적 시차 가 1 시간 미만인 환자는 87 명, 1 시간 이상 2 시간 미만인 환 자는 63명, 2시간 이상의 사회적 시차를 보이는 환자는 30명 이었다. 사회적 시차를 이렇게 세 그룹으로 분류하여, 그룹 간의 일반적 특성과 MCTQ 지표 간 차이를 Table 1에 제시 하였다.

세 그룹간 연령 및 성별 비율에서는 차이를 보이지 않았고, 현재 음주 중인 대상자의 비율, 고혈압을 동반한 대상자의 비율, 당뇨병을 동반한 대상자의 비율, 체질량지수는 세 그 룹간 차이를 보이지 않았다. 현재 흡연 중인 대상자의 비율 과 $\mathrm{NC}$ 는 세 그룹간 유의한 차이를 보였고 $(p<0.05)$, 사회적 시차가 2시간 이상일 때 그 값이 가장 컸지만, Scheffe의 사 후분석에서는 그룹 간 유의한 차이를 보이지 않았다. 수면 
기간과 중간 수면 시각은 근무일에는 세 그룹간 차이가 없 었으나, 자유일에는 세 그룹간 유의한 차이를 보였으며, 사 회적 시차가 큰 그룹에서 수면 기간이 길고 중간 수면 시각 이 늦었다 $(p<0.001) . \mathrm{ESS}$ 와 $\mathrm{K}-\mathrm{BDI}-\mathrm{II}$ 는 그룹간 차이를 보 이지 않았다.

\section{사회적 시차에 따른 수면다원검사 결과 비교}

사회적 시차에 따른 그룹간의 수면다원검사 결과를 Table 2에 제시하였다. 수면 지표들 중에서는 REM 수면의 비중이 세 그룹간 차이가 나기는 하였으나, 각각의 값은 모두 정상 범위에 속하였다.

Table 1. Demographics and MCTQ parameters parameters

\begin{tabular}{|c|c|c|c|c|c|c|}
\hline Variables & $\begin{array}{c}\text { Total } \\
(\mathrm{n}=180)\end{array}$ & $\begin{array}{c}\mathrm{SJL}<1 \mathrm{hr} \mathrm{a}^{\mathrm{a}} \\
(\mathrm{n}=87)\end{array}$ & $\begin{array}{c}1 \leq \mathrm{SJL}<2 \mathrm{hr}^{\mathrm{b}} \\
(\mathrm{n}=63)\end{array}$ & $\begin{aligned} & S J L \geq 2 h^{c} \\
&(n=30)\end{aligned}$ & $p$ & Post-hoc \\
\hline Age, y & $38.3 \pm 8.0$ & $39.0 \pm 7.4$ & $38.7 \pm 8.0$ & $35.1 \pm 9.1$ & 0.060 & \\
\hline Male, n (\%) & $168(93.3)$ & $79(90.8)$ & $60(95.2)$ & $29(96.7)$ & 0.411 & \\
\hline Current smoker, n (\%) & $46(25.6)$ & $20(23.0)$ & $13(20.6)$ & $13(43.3)$ & $0.048^{*}$ & \\
\hline Current alcohol drinker, n (\%) & $128(71.1)$ & $63(72.4)$ & $42(66.7)$ & $23(76.7)$ & 0.573 & \\
\hline Hypertension, n (\%) & $35(19.4)$ & $18(20.7)$ & $11(17.5)$ & $6(20.0)$ & 0.884 & \\
\hline Diabetes, n (\%) & $8(4.4)$ & $3(3.4)$ & $5(7.9)$ & $0(0.0)$ & 0.184 & \\
\hline BMI, kg/m² & $28.4 \pm 5.0$ & $27.7 \pm 4.1$ & $28.5 \pm 5.1$ & $30.0 \pm 6.7$ & 0.104 & \\
\hline $\mathrm{NC}, \mathrm{cm}$ & $40.8 \pm 3.5$ & $40.2 \pm 3.1$ & $41.2 \pm 3.5$ & $41.8 \pm 4.2$ & $0.047^{*}$ & \\
\hline SDW, hr & $6.0 \pm 1.2$ & $6.1 \pm 1.2$ & $6.2 \pm 1.3$ & $6.0 \pm 1.1$ & 0.914 & \\
\hline SDF, hr & $7.2 \pm 1.5$ & $6.7 \pm 1.3$ & $7.5 \pm 1.4$ & $8.3 \pm 1.2$ & $<0.001^{*}$ & $\mathrm{a}<\mathrm{b}<\mathrm{c}$ \\
\hline MSW, h:min & 03:45 $\pm 01: 09$ & $03: 56 \pm 01: 22$ & $03: 30 \pm 01: 58$ & $03: 43 \pm 00: 38$ & 0.068 & \\
\hline MSF, h:min & $04: 54 \pm 01: 21$ & $04: 23 \pm 01: 22$ & 05:00 $\pm 01: 00$ & $06: 14 \pm 00: 52$ & $<0.001^{*}$ & $\mathrm{a}<\mathrm{b}<\mathrm{c}$ \\
\hline MSFsc, h:min & $04: 20 \pm 01: 22$ & $04: 05 \pm 01: 26$ & $04: 18 \pm 01: 16$ & 05:05 $\pm 01: 05$ & $0.002^{*}$ & $\mathrm{a}, \mathrm{b}<\mathrm{c}$ \\
\hline SJL, hr & $1.2 \pm 0.8$ & $0.5 \pm 0.4$ & $1.5 \pm 0.3$ & $2.5 \pm 0.5$ & $<0.001^{*}$ & $\mathrm{a}<\mathrm{b}<\mathrm{c}$ \\
\hline ESS & $10.4 \pm 4.4$ & $10.0 \pm 4.3$ & $11.1 \pm 4.6$ & $10.3 \pm 4.3$ & 0.315 & \\
\hline BDI-II & $10.8 \pm 7.8$ & $11.8 \pm 8.2$ & $10.0 \pm 7.4$ & $9.9 \pm 7.6$ & 0.315 & \\
\hline
\end{tabular}

${ }^{*} p<0.05$. MCTQ: Munich Chronotype Questionnaire, BMI: body mass index, NC: neck circumference, SDW: sleep duration on work days, SDF: sleep duration on free days, MSW: mid-sleep time on work days, MSF: mid-sleep time on free days, MSFsc: mid-sleep time on free days corrected for sleep debt accumulated over the work week, SJL: social jetlag, ESS: Epworth Sleepiness Scale, BDI: Beck Depression Inventory

Table 2. PSG parameters

\begin{tabular}{|c|c|c|c|c|c|c|}
\hline Variables & $\begin{array}{c}\text { Total } \\
(\mathrm{n}=180)\end{array}$ & $\begin{array}{c}\text { SJL }<1 h^{\mathrm{a}} \\
(\mathrm{n}=87)\end{array}$ & $\begin{array}{c}1 \leq \mathrm{SJL}<2 \mathrm{hr}^{\mathrm{b}} \\
(\mathrm{n}=63)\end{array}$ & $\begin{array}{c}\mathrm{SJL} \geq 2 \mathrm{hr}^{\mathrm{c}} \\
(\mathrm{n}=30)\end{array}$ & $p$ & Post-hoc \\
\hline TST, min & $365.0 \pm 59.8$ & $361.6 \pm 58.5$ & $370.1 \pm 54.8$ & $364.1 \pm 73.3$ & 0.694 & \\
\hline SL, min & $10.8 \pm 19.9$ & $10.9 \pm 18.8$ & $11.5 \pm 24.7$ & $8.8 \pm 9.0$ & 0.833 & \\
\hline N1 sleep \% & $23.4 \pm 13.2$ & $22.0 \pm 13.0$ & $22.1 \pm 11.5$ & $27.1 \pm 16.5$ & 0.211 & \\
\hline N2 sleep \% & $50.3 \pm 10.9$ & $50.7 \pm 11.3$ & $50.5 \pm 10.3$ & $48.5 \pm 11.4$ & 0.627 & \\
\hline N3 sleep $\%$ & $6.7 \pm 7.3$ & $6.6 \pm 7.0$ & $6.5 \pm 7.5$ & $7.1 \pm 7.9$ & 0.928 & \\
\hline REM sleep \% & $19.7 \pm 6.0$ & $19.6 \pm 6.0$ & $20.9 \pm 5.2$ & $17.2 \pm 6.9$ & $0.021^{*}$ & $b>c$ \\
\hline WASO, \% & $12.2 \pm 9.8$ & $12.3 \pm 10.2$ & $12.6 \pm 9.5$ & $11.3 \pm 9.3$ & 0.840 & \\
\hline Spontaneous AI, /h & $3.2 \pm 3.0$ & $3.4 \pm 3.2$ & $3.5 \pm 3.1$ & $2.4 \pm 1.9$ & 0.210 & \\
\hline $\mathrm{AHI}, / \mathrm{h}$ & $38.2 \pm 27.4$ & $37.4 \pm 25.5$ & $36.9 \pm 30.0$ & $43.4 \pm 27.0$ & 0.528 & \\
\hline Apnea index, /h & $17.5 \pm 23.1$ & $15.3 \pm 19.7$ & $17.0 \pm 25.2$ & $25.0 \pm 27.0$ & 0.259 & \\
\hline ODI, /h & $33.5 \pm 27.2$ & $32.1 \pm 25.1$ & $32.9 \pm 30.4$ & $38.7 \pm 26.3$ & 0.507 & \\
\hline Apnea max length, sec & $46.1 \pm 24.9$ & $47.3 \pm 27.8$ & $41.8 \pm 21.6$ & $51.3 \pm 22.3$ & 0.195 & \\
\hline LoS, $\%$ & $80.7 \pm 9.4$ & $81.1 \pm 9.0$ & $81.9 \pm 8.5$ & $76.8 \pm 11.2$ & $0.036^{*}$ & $a, b>c$ \\
\hline
\end{tabular}

${ }^{*} p<0.05$. PSG: polysomnography, SJL: social jetlag, TST: total sleep time, SL: sleep latency, WASO: wakefulness after sleep onset, AI: arousal index, AHI: apnea-hypopnea index, ODI: oxygen desaturation index, LoS: lowest oxygen saturation 
Table 3. Partial Spearman correlation analysis between social jetlag and parameters

\begin{tabular}{lllllll}
\hline & \multicolumn{1}{c}{ SJL } & BMI & NC & AHI & ODI & LoS \\
\hline SJL & 1 & & & & & \\
BMI & $0.149^{*}$ & 1 & & & & \\
NC & $0.196^{*}$ & $0.752^{*}$ & 1 & & & \\
AHI & 0.102 & $0.530^{*}$ & $0.526^{*}$ & 1 & & \\
ODI & 0.118 & $0.571^{*}$ & $0.546^{*}$ & $0.983^{*}$ & 1 & \\
LoS & $-0.154^{*}$ & $-0.595^{*}$ & $-0.534^{*}$ & $-0.718^{*}$ & $-0.745^{*}$ & 1 \\
\hline
\end{tabular}

Spearman rho values are presented. ${ }^{*} p<0.05$. SJL: social jetlag, BMI: body mass index, NC: neck circumference, AHI: apnea-hypopnea index, ODI: oxygen desaturation index, LoS: lowest oxygen saturation

수면 무호흡의 중증도를 나타내는 지표인 $\mathrm{AHI}$ 는 2시간 이상의 사회적 시차를 보이는 그룹에서 가장 높은 값을 보 이기는 하였으나, 통계적 유의성은 없었다. 또한 수면 무호 흡의 또 다른 중증도 척도인 ODI도 2시간 이상의 사회적 시 차를 보이는 그룹에서 가장 높은 값을 보이기는 하였으나, 통계적 유의성은 없었다. 하지만 사회적 시차가 2시간 이상 인 그룹에서 lowest oxygen saturation $(\mathrm{LoS})$ 값이 가장 낮았

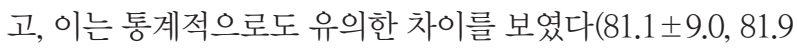
$\pm 8.5,76.8 \pm 11.2, p<0.05)$. 무호흡의 최대 지속시간은 세 그 룹간의 차이가 보이지 않았다.

\section{사회적 시차와 신체계수 및 수면 지표들 간의 상관분석}

사회적 시차에 큰 영향을 미치는 나이와 성별을 보정한 후, 사회적 시차는 $\mathrm{BMI}(\mathrm{rho}=0.149, p=0.046)$ 및 $\mathrm{NC}(\mathrm{rho}=0.196$, $p=0.009$ )와는 양의 상관관계를 보였다. 사회적 시차는 OSA 의 중증도 지표인 $\mathrm{AHI}$ 및 $\mathrm{ODI}$ 와는 유의한 상관관계를 보이 지 않았지만, 무호흡의 $\operatorname{LoS}(\mathrm{rho}=-0.154, p=0.040)$ 과 음의 상 관관계를 보이는 것을 확인할 수 있었다. 상관분석 결과는 Table 3에 제시하였다.

\section{고 찰}

치료받지 못한 OSA는 뇌혈관질환 및 심혈관질환의 발병 과 그로 인한 사망률 등의 연관성이 밝혀지면서 중요도가 높아졌다. 잘 알려진 OSA의 위험 인자들이 많이 있지만, 일 주기 장애와 OSA의 연관성에 대한 연구는 아직 부족한 실 정이다. 본 연구에서는 현대인들이 겪고 있는 만성적 일주기 장애인 사회적 시차가 OSA와 연관성이 있는지 살펴보고자 하였다. 연구 결과, 50 세 미만의 OSA 환자들에서 2시간 이 상의 사회적 시차를 보이는 그룹에서 흡연자의 비율이 많았 고, $\mathrm{NC}$ 가 두꺼웠다. 사회적 시차에 따른 수면의 질은 차이가
없었고, $\mathrm{OSA}$ 의 중증도 척도인 $\mathrm{AHI}$ 도 차이가 없었으나, 무 호흡의 $\operatorname{LOS}$ 값이 사회적 시차가 2시간 이상일 때 유의하게 낮은 결과를 보였다. 또한 나이와 성별을 통제하였을 때, 사 회적 시차는 $\mathrm{BMI}$ 및 $\mathrm{NC}$ 와 양의 상관관계를 보였고, LoS와 는 음의 상관 관계를 보였다. 이를 통해 사회적 시차는 비만, 흡연과 관련이 있고, $\mathrm{LoS}$ 를 제외한 수면 지표와는 관련이 없음을 확인하였다.

사회적 시차가 수면 무호흡에 영향을 미치는 원인 및 기전 은 아직 확실하지 않다. 일주기 장애 자체가 수면 무호흡에 영향을 줄 수 있고, 사회적 시차로 유발되는 동반 질환에 의 해 수면 무호흡이 악화될 수 있다. 아직 그 기전이 명확하지 는 않지만, 선행 연구들에서 일주기 리듬이 수면 무호흡의 발생 및 악화와 관련 있음이 보고되었다. OSA 환자들에서 circadian clock gene의 변화가 발견되었고, 특히 midnight 에 CRY1과 PER3 유전자의 발현 감소가 심한 OSA를 예측 하였다. ${ }^{25}$ 비록 circadian clock gene과 OSA 발생 및 악화 사 이의 시간적 선후관계는 아직 파악되지 않았으나, OSA와 circadian clock gene 사이에 밀접한 관련성이 있음을 알 수 있다. 또 다른 선행 연구에서는 OSA에서 상기도 폐쇄 가능 성(upper airway collapsibility)과 무호흡 지속시간이 내인 성 일주기 패턴을 따른다는 것이 밝혀졌는데, 이른 아침에 해당하는 일주기 단계에서는 수면 무호흡 및 저호흡의 지속 시간이 가장 길고 $\mathrm{AHI}$ 는 낮은 반면, 늦은 오후와 이른 저녁 에 해당하는 일주기 단계에서는 무호흡 및 저호흡의 지속 시 간이 가장 짧고 $\mathrm{AHI}$ 는 높았다. 10,11 아직까지 메커니즘은 여 전히 불분명하지만, 이러한 선행 연구들을 통해 일주기 리듬 이 수면 무호흡 및 저호흡에 영향을 줄 수 있음을 알 수 있다.

또한 이미 알려진 바와 같이 사회적 시차로 인한 수면 박 탈과 일주기 장애는 기초대사율 감소, 식후 혈장 포도당 농 도 증가, 췌장에서의 부적절한 인슐린 분비를 유발하여 비만 및 대사성질환을 초래하고, 흡연 및 음주 등의 substance use 와 관련 있다. ${ }^{14,26}$ 이처럼 사회적 시차로 인해 유발되는 비만, 대사성 질환, 흡연 및 음주 등에 의해 수면 무호흡이 악화될 수 있다. 본 연구에서도 사회적 시차는 BMI 및 $\mathrm{NC}$ 와 양의 상관관계를 보였고, 사회적 시차가 큰 그룹에서 $\mathrm{NC}$ 가 두껍 고, 흡연자의 비율이 높은 것을 확인할 수 있었다.

수면의 질 및 수면 호흡 장애와 관련된 측면에서, 본 연구 결과는 $\operatorname{LOS}$ 외에는 유의한 차이를 보이는 수면 지표는 없었 다. 일반적으로 가장 흔히 사용하는 OSA의 중증도 지표인 $\mathrm{AHI}$ 와 사회적 시차 사이의 유의한 관련성은 관찰되지 않았 지만, LoS값에서는 유의한 관련성을 보였다. AHI가 흔히 사용되는 수면 무호흡의 중증도 척도이지만, 불포화 에피소 드(desaturation episode)가 OSA와 관련된 합병증 발생의 
주요 원인 중 하나이기 때문에, OSA를 진단하는데 있어 무 호흡증의 정도 및 지속시간이 고려되어야 한다. 따라서 본 연구에서 사회적 시차가 2시간 이상일 때 LoS값이 작은 것 도 의미 있는 결과로 해석할 수 있다.

이러한 연구 결과를 바탕으로 본 연구는 다음과 같은 의 의를 갖는다. 최근 일주기 리듬의 중요성이 보고되면서 사회 적 시차와 관련된 연구들이 진행되고 있으나, OSA 환자들을 대상으로 사회적 시차에 대한 연구가 시행된 바가 없다. 따 라서 본 연구를 통해 OSA 환자들에서 사회적 시차에 따른 대상자의 특성을 확인하고, 사회적 시차가 수면호흡장애 및 수면의 질과 연관성이 있는지 탐색하였다는 점에서 의의가 있다. 또한, 본 연구를 통해 OSA 환자 군에서도 사회적 시차 는 비만 및 흡연과 관련이 있다는 것을 확인하였으며, 사회 적 시차가 수면 무호흡의 불포화 정도와 관련 있음을 확인 하였다. 이를 통해 사회적 시차가 수면호흡장애와 관련성이 있다는 근거를 제시하였다는 점에서 의의가 있다.

이러한 의의에도 불구하고, 본 연구에는 몇 가지 제한점이 있다. 첫째, 단편적 연구이기 때문에 사회적 시차와 수면 무 호흡의 관련성을 파악할 수는 있지만, 이들 간의 선후관계를 파악하기는 어렵다는 것이다. 사회적 시차로 인해 수면 무호 흡이 악화되었는지, 반대로 수면 무호흡의 악화로 인한 수면 의 질 저하가 사회적 시차에 영향을 미쳤는지는 알 수 없다. 둘째, 사회적 시차가 수면 무호흡을 악화시키는 기전을 명확 히 밝힐 수 없었다. 앞서 제시한 바와 같이, 사회적 시차로 인 한 일주기 장애 자체가 직접적인 원인인지 또는 사회적 시 차로 인해 동반되는 질환이 원인이 되는지를 밝히지는 못하 였다. 셋째, 연구 설계 과정에서 단일기관에서 적은 수의 대 상자로 분석하였고, 흡연 및 음주 상태 및 동반질환에 대한 조사가 충분하지 못하였다. 넷째, 환자 모집 과정에서 여성의 비율이 적은 것도 연구의 제한점이다. 여성의 경우 주로 폐경 후 OSA의 유병률이 높기 때문에, 50세 미만의 OSA 환자를 대상으로 한 본 연구에는 여성 대상자가 적었다. 하지만 일 주기장애는 성별에 따라 그 특성이 다를 수 있기 때문에, 여 성의 비율이 적은 것이 본 연구의 제한점이 될 수 있다. 향후 이러한 제한점들을 고려한 후속 연구를 통해 사회적 시차와 수면 무호흡 간의 연관성을 보다 명확히 하는 과정이 필요 하다.

결론적으로, 사회적 시차는 OSA의 위험인자인 비만과 관 련이 있고, 수면 무호흡에 영향을 미칠 수 있다. 그러므로 $\mathrm{MCTQ}$ 를 이용해 환자들의 사회적 시차를 확인하고, 이것의 교정 중요성에 대해 설명하는 것도 진료의 중요한 부분이 될 수 있을 것으로 판단한다.

\section{Acknowledgments}

This research was supported by Samsung Biomedical Research Institute grant (OTC1190671).

\section{Conflicts of Interest}

The authors have no potential conflicts of interest to disclose.

\section{ORCID iDs}

Hyunjin Jo

Eunhee Jang

Su Jung Choi

Sooyeon Suh

Eun Yeon Joo https://orcid.org/0000-0001-9563-1849 https://orcid.org/0000-0003-1121-869X https://orcid.org/0000-0003-2171-7441 https://orcid.org/0000-0003-0644-8634 https://orcid.org/0000-0003-1233-959X

\section{Author Contributions}

Conceptualization: Eun Yeon Joo, Hyunjin Jo, Sooyeon Suh. Data curation: Eun Yeon Joo, Hyunjin Jo, Su Jung Choi. Formal analysis: Hyunjin Jo, Eunhee Jang. Investigation: Hyunjin Jo, Su Jung Choi. Methodology: Hyunjin Jo, Eun Yeon Joo, Su Jung Choi. Supervision: Eun Yeon Joo. Writing_original draft: Hyunjin Jo. Writing_review \& editing: Eun Yeon Joo, Hyunjin Jo.

\section{REFERENCES}

1. Dempsey JA, Veasey SC, Morgan BJ, O’Donnell CP. Pathophysiology of sleep apnea. Physiol Rev 2010;90:47-112. https://doi.org/10.1152/ physrev.00043.2008.

2. Kim J, In K, Kim J, et al. Prevalence of sleep-disordered breathing in middle-aged Korean men and women. Am J Respir Crit Care Med 2004;170:1108-1113. https://doi.org/10.1164/rccm.200404-519OC.

3. Chen YH, Keller JK, Kang JH, Hsieh HJ, Lin HC. Obstructive sleep apnea and the subsequent risk of depressive disorder: a populationbased follow-up study. J Clin Sleep Med 2013;9:417-423. https://doi. org/10.5664/jcsm. 2652 .

4. Choi JW, Song JS, Lee YJ, Won TB, Jeong DU. Increased mortality in relation to insomnia and obstructive sleep apnea in Korean patients studied with nocturnal polysomnography. J Clin Sleep Med 2017;13:4956. https://doi.org/10.5664/jcsm.6386.

5. Marin JM, Agusti A, Villar I, et al. Association between treated and untreated obstructive sleep apnea and risk of hypertension. JAMA 2012;307:2169-2176. https://doi.org/10.1001/jama.2012.3418.

6. Marshall NS, Wong KK, Phillips CL, Liu PY, Knuiman MW, Grunstein RR. Is sleep apnea an independent risk factor for prevalent and incident diabetes in the Busselton Health Study? J Clin Sleep Med 2009; 5:15-20. https://doi.org/10.5664/jcsm.27387.

7. Yaggi HK, Concato J, Kernan WN, Lichtman JH, Brass LM, Mohsenin V. Obstructive sleep apnea as a risk factor for stroke and death. $N$ Engl J Med 2005;353:2034-2041. https://doi.org/10.1056/NEJMoa043104.

8. Young T, Finn L, Peppard PE, et al. Sleep disordered breathing and mortality: eighteen-year follow-up of the Wisconsin sleep cohort. Sleep 2008;31:1071-1078. https://doi.org/10.5665/sleep/31.8.1071.

9. Lee W, Nagubadi S, Kryger MH, Mokhlesi B. Epidemiology of obstructive sleep apnea: a population-based perspective. Expert Rev Respir Med 2008;2:349-364. https://doi.org/10.1586/17476348.2.3.349.

10. Butler MP, Smales $\mathrm{C}, \mathrm{Wu} \mathrm{H}$, et al. The circadian system contributes to apnea lengthening across the night in obstructive sleep apnea. Sleep 2015;38:1793-1801. https://doi.org/10.5665/sleep.5166.

11. El-Chami M, Shaheen D, Ivers B, et al. Time of day affects the frequency and duration of breathing events and the critical closing pressure during NREM sleep in participants with sleep apnea. J Appl Physiol (1985) 2015;119:617-626. https://doi.org/10.1152/japplphysiol.00346.2015.

12. Paciorek M, Korczyński P, Bielicki P, Byśkiniewicz K, Zieliński J, Chazan R. Obstructive sleep apnea in shift workers. Sleep Med 2011;12: 
274-277. https://doi.org/10.1016/j.sleep.2010.06.013.

13. Roenneberg T, Allebrandt KV, Merrow M, Vetter C. Social jetlag and obesity. Curr Biol 2012;22:939-943. https://doi.org/10.1016/j.cub.2012. 03.038 .

14. Wittmann M, Dinich J, Merrow M, Roenneberg T. Social jetlag: misalignment of biological and social time. Chronobiol Int 2006;23:497509. https://doi.org/10.1080/07420520500545979.

15. Parsons MJ, Moffitt TE, Gregory AM, et al. Social jetlag, obesity and metabolic disorder: investigation in a cohort study. Int J Obes (Lond) 2015;39:842-848. https://doi.org/10.1038/ijo.2014.201.

16. Wong PM, Hasler BP, Kamarck TW, Muldoon MF, Manuck SB. Social jetlag, chronotype, and cardiometabolic risk. J Clin Endocrinol Metab 2015;100:4612-4620. https://doi.org/10.1210/jc.2015-2923.

17. Koopman ADM, Rauh SP, van 't Riet E, et al. The association between social jetlag, the metabolic syndrome, and type 2 diabetes mellitus in the general population: the new Hoorn study. J Biol Rhythms 2017;32: 359-368. https://doi.org/10.1177/0748730417713572.

18. Ryu HR, Kim IY, Suh S. Gender differences in the relationship between social jet lag, depression, and obesity in Korean children and adolescents. J Sleep Med 2015;12:39-46. https://doi.org/10.13078/ jsm.15008.

19. Berry RB, Brooks R, Gamaldo C, et al. AASM scoring manual updates for 2017 (version 2.4). J Clin Sleep Med 2017;13:665-666. https://doi. org/10.5664/jcsm.6576.

20. Roenneberg T, Wirz-Justice A, Merrow M. Life between clocks: daily temporal patterns of human chronotypes. J Biol Rhythms 2003;18:8090. https://doi.org/10.1177/0748730402239679.

21. Suh S, Kim SH, Ryu H, Choi SJ, Joo EY. Validation of the Korean Munich Chronotype Questionnaire. Sleep Breath 2018;22:773-779. https:// doi.org/10.1007/s11325-017-1609-z.

22. Choi SJ, Suh S, Joo EY. Assessing sleep-wake pattern and chronotype with the Korean Munich ChronoType for Shift-Workers in shift working nurses. J Sleep Med 2017;14:23-35. https://doi.org/10.13078/jsm.17004.

23. Cho YW, Lee JH, Son HK, Lee SH, Shin C, Johns MW. The reliability and validity of the Korean version of the Epworth sleepiness scale. Sleep Breath 2011;15:377-384. https://doi.org/10.1007/s11325-010-0343-6.

24. Beck AT, Steer RA, Brown GK. Manual for the beck depression inventory-II. San Antonio, TX: Psychological Corporation, 1996.

25. Yang MY, Lin PW, Lin HC, et al. Alternations of circadian clock genes expression and oscillation in obstructive sleep apnea. J Clin Med 2019; 8:1634. https://doi.org/10.3390/jcm8101634.

26. Buxton OM, Cain SW, O'Connor SP, et al. Adverse metabolic consequences in humans of prolonged sleep restriction combined with circadian disruption. Sci Transl Med 2012;4:129ra43. https://doi.org/ 10.1126/scitranslmed.3003200. 